\title{
BERPIKIR KRITIS : STUDENT CENTERED LEARNING (SCL) DAN RECIPROCAL TEACHING
}

\author{
Yuyun Suhariami \\ e-mail:yuyun.suhariami@gmail.com \\ Lilik Sri Hariani \\ e-mail: liliksrihariani@unikama.ac.id \\ Riril Mardiana Firdaus \\ e-mail: ririlmardiana@unikama.ac.id
}

(Program Studi Pendidikan Ekonomi, Fakultas Ekonomika dan Bisnis, Universitas Kanjuruhan, Malang)

\begin{abstract}
This study discusses the Student Centered Learning (SCL) Approach, Reciprocal Teaching Learning Model, and Critical Thinking Ability in Ma'arif 02 Islamic Middle School Malang, This study aims to analyze: (1) The Effect of the Student Centered Learning (SCL) Approach, Model Reciprocal Teaching Learning on Critical Thinking Ability in Grade VIII Students of Ma'arif 02 Islamic Middle School Malang City (2) The Effect of Student Centered Learning (SCL) Approach on Critical Thinking Ability in Students (3) The Effect of Reciprocal Teaching Learning Model on Thinking Ability learners. This research uses a quantitative approach, this type of research is ex post facto. The statistical method of research uses multiple linear regression. The population in this study were students of class VIII 2018/2019 school year, with the use of research sampling techniques that are simple random sampling with a total of 100 students or $30 \%$ of the population. Data analysis techniques in this study used the classical assumption test. The results of this study indicate that there is a positive effect on the approach of student centered learning and reciprocal teaching learning models on critical thinking skills. The results of this study concluded that the student centered learning approach and the reciprocal teaching learning model can influence students' thinking skills
\end{abstract}

Keywords : Student Centered Learning (SCL), Reciprocal Teaching, Critical Thinking

\begin{abstract}
Abstrak: Penelitian ini membahas tentang Pendekatan Student Centered Learning(SCL), Model Pembelajaran Reciprocal Teaching, dan Kemampuan Berpikir Kritis di SMP Islam Ma'arif 02 Kota Malang, Penelitian ini bertujuan untuk menganalisis: (1) Pengaruh Pendekatan Student Centered Learning(SCL), Model Pembelajaran Reciprocal Teaching terhadap kemampuan berpikir kritis pada peserta didik kelas VIII SMP Islam Ma'arif 02 Kota Malang(2) Pengaruh Pendekatan Student Centered Learning(SCL) terhadap kemampuan berpikir kritis pada peserta didik (3) Pengaruh Model Pembelajaran Reciprocal Teaching terhadap kemampuan berpikir pada peserta didik. Penelitian ini menggunakan pendekatan kuantitatif, jenis penelitian ini adalah ex post facto. Metode statistik penelitian menggunakan regresi linier berganda. Populasi dalam penelitian ini adalah peserta didik kelas VIII tahun pelajaran 2018/2019, dengan penggunaan teknik pengambilan sampel penelitian yaitu simple random sampling dengan jumlah 100 peserta didik atau $30 \%$ dari populasi. Teknik analisis data dalam penelitian ini menggunakan uji asumsi klasik. Hasil penelitian ini menunjukkan bahwa ada pengaruh positif tethadap pendekatan student centered learning dan model pembelajaran reciprocal teaching terhadap kemampuan berpikir kritis. Hasil penelitian ini disimpulkan bahwa pendekatan student centered learning dan model pembelajaran reciprocal teaching dapat mempengaruhi kemampuan berpikir pada peserta didik
\end{abstract}

Kata kunci : Student Centered Learning(SCL), Reciprocal Teaching, Berpikir Kritis 


\section{PENDAHULUAN}

Seiring berkembangnya zaman, pendidikan di Indonesia semakin meningkat dan terus mengalami perubahan secara signifikan sehingga menyebabkan pola pikir yang juga berubah, dari yang awam menjadi semakin modern. Tercantum dalam Undang- Undang RI Nomor 20 tahun 2003 tentang Sistem Pendidikan Nasional Bab 1 Pasal 1 yaitu Pendidikan merupakan suatu usaha sadar dan terencana untuk mewujudkan suasana belajar dan proses pembelajaran agar peserta didik secara aktif mengembangkan potensi dirinya untuk memiliki kekuatan spiritual keagamaan, pengendalian diri, kepribadian, kecerdasan, akhlak mulia, serta keterampilan yang diperlukan dirinya, masyarakat, bangsa dan negara. Peserta didik akan mampu dalam memecahkan masalah yang dihadapinya, baik dalam kehidupan sehari- hari di sekolah maupun diluar sekolah. Pendidikan di Indonesia saat ini masih menitik beratkan pada kemampuan ranah kognitif peserta didik, tetapi pada Permen Diknas RI Nomor 24 Tahun 2006 pengembangan mata pelajaran Ilmu Pengetahuan Sosial (IPS) dengan memiliki kemampuan dasar dapat berpikir secara logis dan kritis, serta rasa ingin tahu, inkuiri, dapat memecahkan masalah, dan memiliki keterampilan dalam kehidupan sosial. Tujuan yang akan dicapai pada pembelajaran IPS adalah berpikir kritis. Pengembangan kemampuan berpikir kritis dapat dijadikan sebagai salah satu titik berat dalam pembelajaran IPS di Sekolah.

Dunia pendidikan mengajarkan bagaimana keterampilan berpikir kritis itu dimiliki oleh setiap peserta didik sehingga cara belajar siswa dapat lebih baik lagi. Terdapat tiga alasan dalam melatih kemampuan berpikir kritis (Genius Learning Strategi, 2007) yaitu : (1) Dapat mengerti informasi yang ada, (2) Dapat memiliki kualitas kemampuan berpikir, (3) Memiliki hasil yang berkualitas. Sistem pembelajaran konvensional (faculty teaching) merupakan salah satu sistem pembelajaran yang berlaku di Indonesia, di mana kurang sesuai dengan perkembangan ilmu pengetahuan dan teknologi yang semakin pesat. Peserta didik harus belajar lebih aktif, mandiri, sesuai dengan keadaan lingkungan masing- masing sekolah dan perkembangan Ilmu Pengetahuan dan Teknologi khususnya dalam dunia pendidikan. Peserta didik harus mampu mandiri dalam pengoptimalan belajarnya melalui penyeimbangan kemampuan kognitif dan emosional. Maka dari itu perlu adanya pendekatan Student Centered Learning (SCL).

Pembelajaran di dalam kelas, peserta didik perlu mengoptimalkan kemampuannya agar menjadi kepribadian yang lebih mandiri, kreatif dan objektif serta berkarakter dalam hal penampilan, sikap dan tingkah lakunya. Maka dari itu, agar menjadi peserta didik yang memiliki kualitas tingkah laku tinggi harus meningkatkan proses belajarnya. Melalui strategi pembelajaran yang bersifat kontruktivistik dan learning community yaitu pada pembelajaran cooperative learning memiliki bermacam- macam model pembelajara yang dat dikembangkan salah satunya adalah Reciprocal Teaching (Muhfaroyin 2009). Model Reciprocal Teaching adalah salah satu dari pengajaran yang direncanakan melalui strategi kognitif dapat menjadikan siswa lebih memahami sesuatu secara kritis. model pembelajaran reciprocal teaching ini peserta didik dapat mempelajari tiga strategi dalam memahami dan mengatur diri lebih spesifik, yaitu : (1) Dapat memprediksi materi yang akan dipelajari nanti, (2) Dapat mengklarifikasikan sebuah istilah- istilah sulit yang ditemuinya, (3) Dapat mengajukan pertanyaan tentang apa yang belum dipahami dan merangkum sebuah bacaan yang dipelajari (Qohar 2010). 
SMP Islam MA'arif 02 Malang sebagai salah satu sekolah menengah pertama islam yang ada di kota Malang peserta didik mampu berpikir kritis. Berpikir kritis dapat dimiliki peserta didik melalui pendekatan student centered learning dan model pembelajaran reciprocal teaching dengan baik.

Peserta didik kelas VIII salah satu dari beberapa kelas yang ada di SMP Islam Ma'arif 02 Malang yang telah memiliki kemampuan berpikir kritis pada saat pembelajaran di kelas khususnya mata pelajaran ilmu pengetahuan sosial (IPS). Hasil pengamatan yang di lakukan di SMP Islam Ma'arif 02 Malang kelas VIII, peserta didik saat ini sedang menempuh pelajaran IPS. Kenyataannya saat mengikuti pembelajaran di kelas pada mata pelajaran IPS, peserta didik selalu meningkatkan kemampuan kognitifnya saja tidak dengan kemampuannya dalam hal berpikir khususnya dalam berpikir kritis. Rendahnya kemampuan siswa dalam berpikir kritis salah satunya dapat diamati melalui proses belajar yang masih belum dapat mandiri. Peserta didik masih mengandalkan penjelasan dari guru dalam setiap pembelajaran di kelas, tidak berusaha untuk mencari informasi sendiri dengan sumber yang dipercaya. Adanyan model pembelajaran reciprocal teaching berpengaruh dalam meningkatkan kemampuan berpikir ktitis pada peserta didik (Adiwijaya, 2016).

Penelitian yang dilakukan oleh Mulyaningrum (2017) berjudul pengaruh model pembelajaran reciprocal teaching berbantu media pitrorial riddle terhadap kemampuan berpikir kritis dan hasil belajar kognitif siswa. Kesimpulan dari hasil penelitian pada variabel model pembelajaran reciprocal teaching, media pitrorial riddle berpengaruh positif terhadap kemampuan tanpa menggunakan model dan berpengaruh positif pula pada hasil belajar kognitif siswa dengan taraf signifikan. Penelitian yang dilakukan Setiawan, dkk (2016) berjudul pengaruh strategi pembelajaran reciprocal teaching terhadap kemampuan berpikir kritis biologi siswa SMA Islam Al- Ma'arif Singosari Malang. Penelitian pada variabel strategi pembelajaran reciprocal teaching berpengaruh secara signifikan terhadap kemampuan berpikir kritis pada siswa SMA Islam Al- Ma'arif Singosari Malang. Tujuan dari diadakannya penelitian ini adalah 1) Untuk menganalisis pengaruh Pendekatan Student Centered Learning (SCL) dan Model Pembelajaran Reciprocal Teaching terhadap Kemahiran Berpikir Kritis Siswa. 2) Untuk menganalisis pengaruh pengaruh Pendekatan Student Centered Learning terhadap Kemahiran Berpikir Kritis Siswa. 3) Untuk menganalisis pengaruh Model Pembelajaran Reciprocal Teaching terhadap Kemahiran Berpikir Kritis Siswa.

\section{TINJAUAN PUSTAKA}

Berpikir kritis adalah sebuah proses berpikir tingkat tinggi yang dapat digunakan untuk pembelajaran konseptual pada peserta didik (Achmad, 2013). Berpikir kritis merupakan pemikiran yang timbul untuk memutuskan sesuatu tentang apa yang dipercaya atau dilakukan, tetapi harus masuk akal dan seharah jalan pikirannya. John Dewey mengatakan, setiap sekolah harus mengajarkan kepada peserta didik bagaimana cara berpikir yang benar. Beliau mendefenisikan berpikir kritis (critical thinking), yaitu: "Aktif, gigih, dan mempertimbangkan dengan cermat mengenai sebuah keyakinan atau pengetahuan dari sudut pandang manapun yang dapat mendukung serta menyimpulkan sesuatu (Surya, 2011).

Haryadi (2014: 887) berprinsip pembelajaran reciprocal teaching mengajarkan peserta didik untuk belajar secara mandiri, dalam hal ini siswa yang berperan dalam penyampaian materi sesuai dengan cara mengajar guru di dalam kelas. Tujuannya agar peserta didik lebih mandiri dalam proses pebelajarannya serta dapat menjelaskan pengetahuan baru yang diperolehnya. Penelitian relevan yang hampir sama yaitu penelitian yang dilakukan oleh Shophia dan Mulyaningrumm (2017) 
berjudul pengaruh model pembelajaran reciprocal teaching berbantu media pitrorial riddle terhadap kemampuan berpikir kritis dan hasil belajar kognitif siswa. Kesimpulan dari hasil penelitian pada variabel model pembelajaran reciprocal teaching, media pitrorial riddle berpengaruh positif terhadap kemampuan tanpa menggunakan model dan berpengaruh positif pula pada hasil belajar kognitif siswa dengan taraf signifikan. Penelitian yang dilakukan Zubaidah, dkk (2016) berjudul pengaruh strategi pembelajaran reciprocal teaching terhadap kemampuan berpikir kritis biologi siswa SMA Islam Al- Ma'arif Singosari Malang. Penelitian pada variabel strategi pembelajaran reciprocal teaching berpengaruh secara signifikan terhadap kemampuan berpikir kritis pada siswa SMA Islam AlMa'arif Singosari Malang.

Menurut Notoadmojo (2010), Sebuah kerangka konsep membahas tentang ketergantungan suatu variabel atau visualisasi hubungan yang dianggap perlu antara satu variabel dengan variabel lainnya yang mana dapat melengkapi dinamika situasi akan diteliti. Hidayat (2014) Kerangka konsep merupakan Justifikasi ilmiah terhadap topik yang dipilih sesuai dengan identifikasi masalah. Kerangka konsep harus didukung dengan landasan teori yang kuat serta ditunjang oleh informasi yang bersumber pada dari beberapa laporan ilmiah, hasil penelitian, jurnal penelitian dan lain-lain.

\section{METODE}

Pendekatan kuantitatif dapat digunakan dalam penelitian ini, dikemukakan oleh Sugiyono (2012: 8).. Jenis penelitian ini adalah Penelitian ex post facto. Penelitian ex post facto bertujuan untuk melacak kembali, jika dimungkinkan, apa yang menjadi faktor penyebab terjadinya sesuatu (Sugiono 2012). Penggunaan metode dalam penelitian ini adalah regresi linier berganda. Ruang lingkup penelitian ini dapat dijelaskan sebagai berikut ini: Pengaruh Pendekatan Student Centered Learning (SCL) dan Model Pembelajaran Reciprocal Teaching terhadap Kemampuan Berpikir Kritis. Obyek Penelitian ini yaitu peserta didik SMP ISLAM Ma'arif 02 MALANG Kelas VIII Tahun Pelajaran 2018/2019 dengan jumlah 330 Peserta Didik. Penelitian ini di laksanakan di SMP Islam Ma'arif 02 Malang Tahun Pelajaran 2018/2019. Teknik pengambilan sampel yang digunakan dalam penelitian ini adalah simple random sampling. Sampel simple random sampling merupakan teknik pengambilan sampel yang memberikan kesempatan yang sama kepada populasi untuk dijadikan sampel (Darmawan 2013: 146). Pengambilan sampel dalam penelitian ini sebanyak 99 peserta didik atau 30\% dari populasi. Sampel yang digunakan sebanyak 99 peserta didik, maka dapat dibulatkan mejadi 100 dengan Alat pengambilan data hanya angket. Analisis penelitian ini menggunakan perhitungan statistik, data harus berupa kuantitatif sebagaimana yang dikemukakan oleh Arikunto (2010:278). Metode analisis yang digunakan dalam penelitian ini yaitu model regresi linear berganda. Regresi linear berganda ini meramalkan suatu keadaan variabel terikat, bila terdapat dua variebel bebas sebagai faktor prediator dimanipulasi (Sugiyono, 2014:277). Maka dari itu dapat disimpulkan bahwa dalam suatu penelitian jika terdapat 2 atau lebih variabel bebas maka dapat menggunakan regresi linear berganda.

\section{HASIL DAN PEMBAHASAN}

Berdasarkan hasil perhitungan statistik dengan bantuan software SPSS 22.00 for windows diperoleh tabel Anova yang menunjukan uji F statistik untuk pengujian hipotesis yang diajukan adalah sebagai berikut: Hasil tes Anova diperoleh nilai F sebesar 42,168 dengan tingkat signifikan $0,000^{\mathrm{b}}$ karena tingkat signifikan lebih kecil dari 0,05 , maka $\mathrm{H}_{0}$ ditolak dan $\mathrm{H}_{1}$ diterima artinya yaitu: 
Pendekatan Student Centered Learning (SCL) ( $\mathrm{X}_{1}$ ) dan Model Pembelajaran Reciprocal Teaching $\left(\mathrm{X}_{2}\right)$, berpengaruh signifikan terhadap Kemampuan Berpikir Kritis $(\mathrm{Y})$ pada Peserta didik di SMP Islam Ma'arif 02 Kota Malang kelas VIII tahun pelajaran 2018/2019.

Pendekatan Student Centered Learning (SCL) merupakan suatu satu faktor yang dapat mempengaruhi kemampuan berpikir kritis pada peserta didik di SMP Islam Ma'arif 02 Kota Malang, karena pembelajaran yang dilakukan di SMP Islam Ma'arif 02 Kota Malang ini berpusat pada peserta didik, maka kemampuan berpikir yang dimiliki peserta didik semakin kritis. Pendekatan pembelajaran yang berlangsung menjadikan peserta didik untuk selalu meningkatkan kemampuan berpikir kritis. Selian itu guru juga memberikan kesempatan kepada peserta didik agar belajar lebih mandiri, dengan kemandirian tersebut maka mempengaruhi kemampuan berpikir kritis yang dimiliki oleh peserta didik. Pendekatan Student Centered Learning (SCL) akan sangat menentukan kemampuan berpikir kritis yang dimiliki peserta didik dalam pembelajaran di dalam kelas.

Salah satu hal yang dapat mempengaruhi kemampuan berpikir kritis yang dimiliki peserta didik selain pendekatan Student Centered Learning (SCL) yang dilakukan oleh guru saat pembelajaran berlangsung, model pembelajaran reciprocal teaching juga sangat mempengaruhi kemampuan peserta didik dalam berpikir. Peserta didik memiliki berbagai macam karakteristik dalam belajar dan menerima setiap pelajaran yang disampaikan oleh guru di dalam kelas tergantung bagaiman peserta didik tersebut. Melalui model pembelajaran reciprocal teaching juga menjadikan peserta didik untuk lebih mandiri dalam setiap proses pembelajaran yang berlangsung. Guru di dalam kelas hanya sebagai fasilitator, selebihnya dikembangkan sendiri oleh peserta didik.

SMP Islam Ma'arif 02 Kota Malang selalu berusaha melakukan pendekatan pembelajaran dengan baik agar peserta didik merasa nyaman dengan ilmu yang disampaikan oleh guru sehingga dapat terserap dengan baik. Selain pendekatan pembelajaran, sekolah juga memberikan model pembelajaran yang bermacam- macam agar peserta didik tidak merasa bosan dengan setiap pembelajaran yang berlangsung. Ketika peserta didik tidak mudah meraa bosan dengan pembelajaran yang dilakukan oleh guru maka peserta didik akan dengan mudah memperoleh ilmu. Ilmu yang diperoleh peserta didik dapat meningkatkan kemampuan berpikir. Samikin meningkat kemampuan berpikir pada peserta didik maka semakin kritis pula peserta didik terhadap sesuatu yang ada disekitanya.

Proses pembelajaran menggunakan pendekatan Student Centered Learning (SCL) dan model pembelajaran reciprocal teaching yang dilakuka oleh guru dikelas maka dapat dipastikan peserta didik tersebut memiliki kemampuan berpikir yang baik terhadap setiap proses pembelajaran. Oleh karena itu pendekatan Student Centered Learning (SCL) dan model pembelajaran reciprocal teaching secara bersama-sama akan berpengaruh terhadap kemampuan berpikir kritis pada peserta didik di SMP Islam Ma'arif 02 Kota Malang yang mana dalam penelitian ini khususnya untuk peserta didik kelas VIII tahun pelajaran 2018/2019.

Berdasarkan nilai $\mathrm{R}^{2}$ yang digunakan untuk mengukur besarnya proporsi dari variabel bebas yang mampu menerangkan variabel dengan Regresi Liniear Berganda. Nilai $\mathrm{R}^{2}$ berkisar 0-1 semakin tinggi nilai $\mathrm{R}^{2}$ maka semakin baik model regresi dalam menjelaskan pengaruh variabel bebas terhadap variabel terikat. Hasil Uji $\mathrm{R}^{2}$ dapat dilihat pada Tabel 2 sebagai berikut:

Tabel 2 Uji $\mathbf{R}^{2}$

Model Summary ${ }^{\mathrm{b}}$

\begin{tabular}{|l|c|c|c|c|}
\hline \multicolumn{5}{|c|}{ Model Summary } \\
\hline Model & R & R Square & Adjusted R & Std. Error of \\
\hline
\end{tabular}




\begin{tabular}{|l|r|r|r|r|}
\hline & & Square & the Estimate \\
\hline 1 &, $682^{\mathrm{a}}$ &, 465 & \multicolumn{3}{|c|}{, 454} & 3,46665 \\
\hline \multicolumn{2}{|l|}{ a. Predictors: (Constant), Model Pembelajaran Reciprocal Teaching (X2), } \\
Pendekatan Student Centered Learning (SCL) (X1) \\
b. Dependent Variable: Berpikir Kritis (Y) \\
\hline \multicolumn{2}{l}{ b. }
\end{tabular}

Sumber: Hasil olahan SPSS versi 22.00 for Windows

Berdasarkan Tabel 2 mengidentifikasikan bahwa berpengaruh antara variabel Pendekatan Student Centered Learning (SCL) ( $\left.\mathrm{X}_{1}\right)$ dan Model Pembelajaran Reciprocal Teaching $\left(\mathrm{X}_{2}\right)$, memiliki koefisien korelasi 0,682 diatas 50\% untuk mencapai angka 1 artinya variabel bebas Pendekatan Student Centered Learning (SCL) $\left(\mathrm{X}_{1}\right)$ dan Model Pembelajaran Reciprocal Teaching $\left(\mathrm{X}_{2}\right)$, secara bersamasama memiliki hubungan yang kuat dengan variabel terikat Kemampuan Berpikir Kritis (Y). Nilai koefisien determinasi ( $\mathrm{R}$ Square) menunjukan besar kontribusi seluruh variabel bebas yaitu Pendekatan Student Centered Learning (SCL) ( $\left.\mathrm{X}_{1}\right)$ dan Model Pembelajaran Reciprocal Teaching $\left(\mathrm{X}_{2}\right)$ terhadap Kemampuan Berpikir Kritis (Y), jadi R Square 0,465 memiliki makna Pendekatan Student Centered Learning (SCL) $\left(\mathrm{X}_{1}\right)$ dan Model Pembelajaran Reciprocal Teaching $\left(\mathrm{X}_{2}\right)$ mampu memberikan kontribusi sebsar 46,5\% terhadap Kemampuan Berpikir Kritis (Y) dengan demikian sisanya dipengaruhi oleh variabel lain yang tidak diteliti.

Berdasarkan Uji $\mathrm{t}$ yang digunakan untuk menguji signifikan pengaruh masing-masing variabel independen yang terdiri dari Pengetahuan Tentang yaitu Student Centered Learning (SCL) ( $\left.\mathrm{X}_{1}\right)$ dan Reciprocal Teaching $\left(\mathrm{X}_{2}\right)$ terhadap Kemampuan Berpikir Kritis (Y), Hasil uji t pada penelitian dapat dilihat pada Tabel 3 sebagai berikut:

Tabel 3 Hasi Uji t (Uji Signifikan Parsial)

\begin{tabular}{|l|l|c|c|c|}
\hline \multicolumn{5}{|c|}{ Coefficients $^{\mathrm{a}}$} \\
\hline Model & (Constant) & T & Sig. & Keterangan \\
\hline & $\begin{array}{l}\text { Pendekatan Student } \\
\text { Centered Learning (SCL) }\end{array}$ & 4,2870 &, 000 & \\
\cline { 2 - 5 } & $\begin{array}{l}\text { Model Pembelajaran } \\
\text { Reciprocal Teaching }\end{array}$ & 2,491 &, 000 & Signifikan \\
\hline \multicolumn{2}{|l|}{ a. Dependent Variabel: Kemampuan Berpikir Kritis } & Signifikan \\
\hline
\end{tabular}

Sumber: Hasil olahan SPSS versi 22.00 for Windows

Berdasrkan Tabel 3 hipotesis penelitian untuk menguji hipotesis kedua $\left(\mathrm{H}_{2}\right)$ adalah sebagai berikut: berdasarkan hasil analisis diperoleh nilai thitung $=4,287$ dengan nilai sig. 0,000 lebih kecil dari 0,05 yang artinya Pendekatan Student Centered Learning (SCL) $\left(\mathrm{X}_{1}\right)$ memiliki pengaruh yang signifikan terhadap Kemampuan Berpikir Kritis (Y) pada peserta didik SMP ISLAM Ma'arif 02 Kota Malang kelas VIII Tahun Pelajaran 2018/2019. Hal ini disebabkan karena pendekatan Student Centered Learning (SCL) merupakan suatu pendekatan pembeljaran yang berpusat pada peserta didik, menjadikan peserta didik lebih aktif dalam proses pembelajaran yang dilakukan didalam kelas.

Pendekatan Student Centered Learning (SCL) dan Model pembelajaran Reciprocal Teaching memiliki pengaruh yang signifikan secara parsial, hal ini disebabkan karena responden menjawab pernyataan dengan konsisten yang menyebabkan data yang dikelolah hasilnya signifikan. Selain itu 
peserta didik kelas VIII tergolong peserta didik yang sudah dapat megikuti proses pembelajaran dengan baik.

Pendekatan Student Centered Learning (SCL) merupakan suatu pendekatan yang harus dimiliki oleh peserta didik dalam proses pembelajaran berlangsung yang mana sebagai dasar untuk menerima ilmu yang disampaikan oleh guru di dalam kelas. Dengan demikian pendekatan Student Centered Learning (SCL) memiliki pengaruh terhadap kemampuan berpikir kritis peserta didik kelas VIII SMP Islam Ma'arif 02 Kota Malang secara simultan dan parsial karena nilainya lebih kecil dari 0,005 .

Hipotesis penelitian untuk menguji hipotesis ketiga $\left(\mathrm{H}_{3}\right)$ adalah sebagai berikut: berdasarkan hasil analisis diperoleh nilai thitung $=2,491$ dengan nilai sig. 0,014 lebih kecil dari 0,05 yang artinya Model Pembelajaran Reciprocal Teaching $\left(\mathrm{X}_{2}\right)$ berpengaruh terhadap Kemampuan Berpikir Kritis (Y) pada peserta didik SMP ISLAM Ma'arif 02 Kota Malang. Model Pembelajaran Reciprocal Teaching merupakan suatu model pembelajaran yang mana juga mengajarkan peserta didik untuk belajar lebih mandiri di dalam kelas. SMP ISLAM Ma'arif 02 Kota Malang selalu memberikan selalu menggunakan pendekatan dan model pembelajaran yang bervariasi dan menciptakan suasana pembelajaran yang lebih menyenangkan agar peserta didik tidak merasa bosan dengan pembelajaran yang sedang berlangsung. Sesuai dengan kemampuan peserta didik, guru memberikan pendekatan dan model pembelajaran. Dengan seperti itu maka peserta didik merasa lebih giat dalam belajar dan peserta didik memutuskan untuk meningkatkan kemampuan belajarnya agar kemampuan berpikir meningkat.

Sesuai dengan jawaban responden dalam angket dapat menunjukkan bahwa guru di SMP ISLAM Ma'arif memberikan pendekatan pembelajaran yang baik, dibuktikan dengan nilai yang diperoleh setiap peserta didik. Peserta didik juga merasa bahwa guru selalu memberikan pendekatan pembelajaran yang bervariasi sesuai dengan kemampuan yang dimiliki oleh peserta didik meskipun peserta didik memiliki kemampuan yang berbeda-beda.

Oleh karena itu dapat disimpulkan bahwa pendekatan student centered learning memiliki pengaruh yang sangat besar terhadap kemampuan berpikir kritis pada peserta didik dalam proses pembeljaran yang berlangsung. Banyak responden yang menyatakan setuju tentang pembelajaran yang berlangsung yakni pendekatan yang digunakan oleh guru sesuai dengan kemampuan peserta didik. Selain itu dari guru sendiri selau berupaya memberikan pembelajaran dengan berbagai macam pendekatan yang mengarah pada hal lebih baik untuk peserta didiknya.

\section{KESIMPULAN}

Berdasarkan hasil analisis yang telah dikemukakan pada bab $\mathrm{V}$, maka dapat ditarik kesimpulan bahwa terdapat pengaruh yang signifikan secara simultan antara pendekatan Student Centered Learning (SCL) dan model pembelajaran reciprocal teaching terhadap kemahiran berpikir kritis peserta didik di SMP Islam Ma'arif 02 Kota Malang, karena tingkat signifikansi memenuhi syarat maka $\mathrm{H}_{01}$ ditolak dan $\mathrm{H}_{a 1}$ diterima. Pada pendekatan Student Centered Learning (SCL) terdapat pengaruh yang signifikan secara parsial terhadap kemahiran berpikir kritis peserta didik. Model Pembelajaran Reciprocal Teaching juga mempunyai pengaruh yang signifikan secara parsial terhadap kemahiran berpikir kritis peserta didik SMP Islam Ma'arif 02 Kota Malang. Berdasarkan kesimpulan diatas, maka saran yang diajukan oleh peneliti guna memberikan manfaat kepada semua pihak yakni 
sebaiknya Guru selalu memberikan pengembangan terhadap suatu pendekatan dan model pembelajarn yang digunakan pada kelas VIII mata pelajaran IPS. Tujuannya agar peserta didik dalam kemampuan dalam berpikir menjadi lebih berkembang, sehingga menjadikan peserta didik lebih kritis dalam menerima setiap proses pembelajaran di dalam kelas. Ketika kemampuan berpikir kriti dimiliki oleh peserta didik, maka peserta didik lebih mudah menerima pembelajarn yang disampaikan oleh guru.

\section{DAFTAR PUSTAKA}

Adi W. Gunawan. 2007. Genius Learning Strategi, Jakarta: PT. Gramedia Pustaka Utama, Cet 3 h. 171

Arikunto. 2010. Prosedur Penelitian: Suatu Pendekatan Praktek. Jakarta: Rineka Cipta.

Darmawan. 2013. Metode Penelitian Kuantitatif. Bandung: Remaja Rosdakarya.

Departemen Pendidikan Nasional. 2003. Undang-Undang Nomor 20 Tahun 2003, Tentang Sistem Pendidikan Nasional, Jakarta: Depdiknas.

Departemen Pendidikan Nasional. 2006 Peraturan Menteri Pendidikan No. 24

Tahun 2006 Tentang Pengembangan Mata Pelajaran Ilmu Pengetahuan Sosial (IPS), Jakarta: Menteri Pendidikan Nasional, 2006).

Hendra Surya. 2011. Strategi Jitu Mencapai Kesuksesan Belajar, Jakarta: Elek Media Komputindo.

Hidayat, A.A..(2014). Metode Penelitian Keperawatan Dan Teknis Analisis Data. Jakarta : Salemba Medika Muhfahroyin. 2009b. Pengaruh Strategi Think Pair Share (TPS) dan Kemampuan

Akademik terhadap Kemampuan Berpikir Kritis Siswa SMA di Kota Metro.

Jurnal Pendidikan dan Pembelajaran. Volume 16 (2): 107-115.

Mulyaningrum \& Shophia. 2017. Pengaruh Model Pembelajaran Reciprocal Teaching Berbantu Media Pitrorial Riddle terhadap Kemampuan Berpikir Kritis dan Hasil Belajar Kognitif Siswa. Jurnal Pendidikan.

Notoatmodjo, S. 2010. Metodologi Penelitian Kesehatan. Jakarta : Rineka Cipta

Sugiyono. 2012. Penelitian Pendidikan Pendekatan Kuantitatif, Kualitatif, dan R dan D. Bandung: Alfabeta.

Sugiyono. 2014. Penelitian Pendidikan Pendekatan Kuantitatif, Kualitatif, dan R dan D. Bandung: Alfabeta.

Susanto, Ahmad. 2013. Teori Belajar dan Pembelajaran. Jakarta: Kencana Prenada Media Grup.

Zubaidah, dkk. 2016. Pengaruh Strategi Pembelajaran Reciprocal Teaching terhadap Kemampuan Berpikir Kritis Biologi Siswa SMA Islam Al-Ma'arif Singosari Malang. Jurnal Pendidikan. Malang: IKIP Budi Utomo. 